\title{
Implementation of Social Culture in Corporate Governance: A Literature Study
}

\author{
Mukhtaruddin Mukhtaruddin ${ }^{1}$, M. Adam ${ }^{1}$, Isnurhadi Isnurhadi ${ }^{1} \&$ Luk Luk Fuadah $^{1}$ \\ ${ }^{1}$ Faculty of Economics, Universitas Sriwijaya, Indonesia \\ Correspondence: Mukhtaruddin Mukhtaruddin, Faculty of Economics, Universitas Sriwijaya, Indonesia.
}

Received: May 24, 2019

Accepted: October 21, 2019

Online Published: November 22, 2019

doi:10.5430/ijfr.v11n1p293

URL: https://doi.org/10.5430/ijfr.v11n1p293

\begin{abstract}
Good corporate governance (GCG) is a principle implemented by the company to ensure that the interests of stakeholders are not neglected. GCG consists of five main pillars which are transparency, accountability, responsiveness, independency, and fairness. In Indonesia, GCG implementation has not been effective enough as it is only necessarry for large companies and the public. The instrument used to assess GCG implementation is not appropriate either, examples of such are its portion, the existence and role of independent commissioners, portion, the existence and role of the audit committee, and ownership structure. This paper analyzes the implementation of culture found in Indonesian people living in GCG system. With the implementation of this social culture, the corporate GCG is better in its implementation because it is built on the noble values of the people. It then became the Pancasila which is the philosophy of Indonesia as such the the GCG implementation is accessed using the Pancasila Corporate Governance Index (PCGI).
\end{abstract}

Keywords: good corporate governance, social culture, Pancasila, Pancasila corporate governance index

JEL Codes: D25, G32, G41, M14

\section{Introduction}

Good corporate governance (GCG) is one of the principles used for increasing efficiency and economic growth as well as improving investor's confidence (Shleifer and Robert, 1997). It involves a set of relationships between company management and the board of commissioners, shareholders and other stakeholders that also provide structures with the aim of monitoring performance (OECD, 2015). Furthermore, GCG provides adequate incentives for the board of commissioners and management with the aim of ensuring the interests of stakeholders are monitored effectively (Sutojo \& John, 2005). Its existence between the company and stakeholders assists to generate the level of trust needed in the economic market. As a result, the cost of capital is lowered and companies' resources become more efficient, and this in turn improves economic growth (Tiwari, 2010; Skare\&Tea, 2016). The GCG framework depends on legal aspects, policy makers and institutional environments (Osborne, 2017; Hill, 2005). The business ethics factor and the company's concern for the environment and social interests also determine the company's reputation in long-term success (Meilina, 2016; Hasan \& Yun, 2017; Bachev, 2018; Lestari et al., 2019; Mukhtaruddin et al., 2019).

In conducting the company's operations, GCG indicators are employed to give high trust to the company. In 2015, Anti-Corruption Clearing House assessed GCG indicators by conducting surveys of three indicators including Doing Business Index (DBI), Corruption Perception Index (CPI), and Global Corruption Barometer (GCB). The results of this survey state that Indonesia is ranked in the world below Singapore, Malaysia, Thailand, Brunei, Vietnam and the Philippines in almost all indicators. Indonesia is only better than Cambodia, Laos and Myanmar. This should be a special concern to be improved in the Indonesian economy as a whole. The low Indonesian GCG indicator is caused by high levels of corruption (Ragawino, 2008; Santosa, 2008; Handoyo, 2011; Pangaribuan, 2013; Sarwono et al., 2018). In 2015, the results of the Asian perceptions of corruption index survey showed that Indonesia's CPI score was 36 as it was placed 15 in Asia and 88 in the world rankings. The Indonesian CPI score was below Singapore, Malaysia and Thailand even though the score and rank rose. Indonesia's ranking is only slightly better than the Philippines, Vietnam and Myanmar. 
Through paying attention to the importance of GCG, Indonesia designed for GCG improvements. In 2000, the country formed a National Committee on Corporate Governance Policy (NCCGP) through the Decree of the Coordinating Minister for the Economy, Finance and Industry. The main task of this committee is to formulate and arrange national policy recommendations of GCG, and initiate and monitor its improvements in Indonesia. In monitoring and evaluating the implementation of GCG, the Indonesian Institute for Corporate Directorship (IICD) was formed with the main task of assessing the level of GCG implementation. Although efforts have been made to monitor, but the implementation has not gone well. Each indicator of the GCG mechanism has problems in its implementation including the board of commissioners, board of independent commissioners, audit committee and ownership structure.

The board of commissioners has the main function of supervising the board of directors. However, the implementation of the duties and functions by them is not yet clear which made the recruitment and orientation system work less, hence the size and composition of the board of commissioners also have no clear arrangements. The board processes at the general meeting of shareholders still need to be improved while interactions between them and the directors are not well established. This has affected the proper regulation of the organizational structure which is a function of the financial information systems needed by them at all times (Muntoro, 2006). The effectiveness of their role has been below par, because they cannot detect the irregularities committed by the company in the form of profit bubbles and income distribution (Lestari \& Murtanto, 2018, Junaedi \& Khoirina, 2017). The independent board of commissioners is not from the company and does not own any of the company's shares. Their role is still not well implemented because they are not appointed through a general meeting of shareholders. In addition, many are not having the neccassary business background yet aged 50 years and above. This thus makes their role in the supervision of and performance for the company, both financial and non-financial performance, limited (Maryati, 2018; Dewi, 2014, Debby, et al., 2014; Siahaan, 2013; Mukhtaruddin, 2014; Agustina, 2017; Adeniyi \& Fadipe, 2018; Odoemelam \& Okafor, 2018).

The audit committee is tasked with providing professional and independent opinions concerning reports submitted to the Board of Commissioner. The report is in the form of corporate policy recommendations and directives for the future such that the company's goals can be achieved effectively. The role of the committee in its implementation does not make a meaningful contribution to the company (Mukhtaruddin, 2014; Adam, et al., 2015; Almaqoushi, 2017; Alqatamin, 2018), even though it is one of the important elements in GCG with set rules governing auditing regarding the number and portion of those who have academic backgrounds from accounting and financial management. However, in its implementation, regulation would not be fulfilled without giving sanctions to companies that did not obey the rules.

Ownership structure is a portion of the company's shareholders consisting of managerial, institutional, family, government, foreign, and public ownerships. In some companies the structure is concentrated in one of the ownerships such as the family. For instance, the dominance of the family is very evident in some company's decision making processes including determining the board of commissioners and directors at the general meeting of shareholders and other policies such as investment policies. With the high investment policy, the possibility of earning profits in the future will be higher, but it will be disadvantageous to shareholders, because it does not distribute dividends (Shyu, 2011, Giovannini, 2010; Dharmadasa, 2014; Tsao, et al, 2009). Similarly, in companies with government concentrated ownership, government intervention and political interests are very dominant in the company's decision-making process making professionalism and commitment less noticeable. Achieving long-term corporate goals is also difficult to achieve because once a change in power or regime occurs, company leaders with concentrated government ownership often get replaced. There have been instances whereby some company leaders get removed in the course of their leadership period due to political reasons and agendas (Situmorang, 2010).

The above problems can also be seen from the participation of Indonesian companies in the Corporate Governance Perception Index. In 2017 only 67 companies in Indonesia were considered to have good GCG implementation as compared to the 26.71 million companies operating in Indonesia (BPS, SE2016). This is an interesting phenomenon to study with the implementation of GCG in Indonesia focusing on indicators that have a role in it. The implementation must be built within the company first, via building a culture and value system in a company that comes from social culture. This social culture concerns human values like spirituality, justice and civilization, unity, leadership and non-profit and shared prosperity. Now by implementing socio-cultural values in GCG, its principles, such as transparency, accountability, responsibility, independence and fairness can be effectively realized.

The differences in the cultural and social orders of each country are causing the difference in the implementation of GCG (Anderson, 2015; Griffin, 2014). The need to develop GCG implementation in Indonesia is seen by considering 
the noble values of the people. Therefore, research will test and discuss the internalization of the noble values in the implementation of corporate governance. The noble values of the nation and the culture of society are the norm to regulate the order of people's lives (Sibarani, 2012). These values are manifested in the basic form of the Pancasila. Pancasila consists of five precepts which include recognition of the noble values associated with the recognition of human rights including religious life, fair and civilized treatment of the people, protection of the integrity of the state, a decision-making process that prioritizes deliberation and agreement and focuses on improving welfare society. The Five principles of Pancasila consist of forty-five points and conduct an analysis of the content of information provided in the annual report. Forty-five points are compared with the disclosures made by the company, thus the index of disclosure of GCG based Pancasila can be calculated (Pancasila Corporate Governance Index=PCGI).

The noble and cultural values of Indonesia gathered in Pancasila create Indonesian GCG that makes it easier to implement and achieve. Thus the main objective of the company to improve stakeholder's gain can be achieved effectively. Although the changes occur in form of space, time, organizational style, and human resources changing, this nonetheless have had minimal effect as the uniqueness of corporate GCG remains well implemented. This means that the substance of the nation's noble values has never disappeared, continues in the people's lives. Therefore, the GCG building will be strong always if GCG is built on the basis of the nation's noble values.

Anderson (2017) explained that culture is very influential on the success of implementing GCG and this is also in line with the research conducted by Ntongho (2016), Price (2018), Lopis, el. al (2007), and Rafiee (2012). It shows that the cultural aspects that exist in the community or within the organization are one of the factors on which the success of implementing GCG depends. Therefore, research explores the noble values and national culture that has grown in the community, which has become a basic foundation of national culture internalized in the implementation of GCG in the company. The noble values in Pancasila are implemented by the company, thus each individual is proud and works with high motivation. Then the company's performance will increase (Hermanto and Rusdin, 2013). In the theory of The Planned of Behavior (TPB) reported that behavior in a company based on noble values and social order has existed for a long time, and that information reader reacts according to the information presented. Therefore, investores would react positively with good PCGI and this in turn increases the stock transaction.

The noble value of the nation in the first principle of Pancasila, the One and Only God, requires a religious life in the company. With high religious values, supervision, control, and individual responsibility will be better because it cannot be hidden from God. With the existing religious values in the company, the policy taken must see the interests of the company individually and its usefulness to the social environment (rahmatin lil alamin) (Baxamusa, 2013; Kusi-Mensah, et al, 2007; Sarapatka; 2016; Rahman, 2002, Cai, 2017). This first principle deals with responsibility in good governance. Religious life requires taking responsibility for all deeds that are done. The existence of religious supervision in the activities will encourage everyone to walk according to the rules and regulations applied.

The second principle of Pancasila is fair and civilized humanity, which deals with issues of justice and equal treatment and no discrimination. Treating all individuals in the company in a fair manner where everyone have rights, obligations, responsibilities, and equality, then each individual would strive to realize their respective duties and responsibilities. Thus each individual does well and is accountable for everything done. Policies taken based on the duties and responsibilities of each individual are reliable and applicable to all, favoring no party (Heiller, 2001; Arshad, et al., 2012; Kalay, 2016; Diab, 2015; Mohameed, 2014). Harmonization of the relations between individuals in the company and it leaders is needeed for the company's sustainability in the future

The third principle of Pancasila is the Indonesian Unity. It deals with the values of unity in the company and encourages more of it in the Indonesian state as a whole. The values of unity and pride in the country must be developed in the company through high tolerance in the face of diversity.Values encourage policy makers in companies to maintain the level of such unity (Jaja, 2014; Harung, 1995; Ordu, 2016) and it also reflects the compactness of all individuals in the company to achieve set goals which serves as the input for investors to make investment decisions in the future.

The fourth principle of Pancasila is People's Leadership, led by wisdom in consultation or representation, which develops great leadership in Indonesia, i.e. (a) In the form of role models, (b) in the midst of encouragement, and (c) in the back of motivating (Dewantara, 1922). One of the keys to the company's success is determined by the leadership style in the company. If a leader possesses all three attributes, then such a person is bound to be of polite character and can easily attain right positions (Imran, 2012; Pradeep, 2011; Koech, 2012).

The fifth principle of Pancasila is social justice for all Indonesian people. It contains national cultural values that are related to the welfare of society in general. The company's strategies to obtain high profits involves the community, therefore the company must pay attention to the welfare of the community around the company. Triple-bottom line 
reporting requires companies to focus on the 3Ps which are profit, people and the planet. Company sustainability requires an increase in profits used for the development of the company. And this company's development policy must be balanced with the community welfare program including shareholders, leaders, employees (Molnar, 2015), because the right company policy encourages the company to do better and move forward in the future. The importance of this information cannot be overemphasized for investors to making a policy of investing in the company

Through interacting with the noble values of the people implementing GCG, individual in the company would have a sense of belonging. And this system targets the development of the individual social order within the company to makes them stay committed to set goals. The policy making process includes all management levels in the company (culture of non-profit), which facilitates proper realization of results. Kotter\&Heskett's (1992) research was conducted for 10 years in 14 of America's best companies and the research showed that the success of a company is a function of the strong supporting culture. The research also stated that; in companies with strong culture, employees tend to cooperate with company leaders, helping business performance increase and creating an extraordinary level in the employees. Similarly, it also helps performance by providing the structure and control needed without having to rely on an inflexible bureaucracy that suppresses the growth of motivation and innovation.

This shows that the implementation of national values in the management of the company causes decisions or policies made to be in allignment and fairness with all parties involved. One of these is the financial policy and it is made in a reasonable and non-discriminating manner. The values expressing this culture are equality and social relation where workers are seen as assets, partners, human being, and a balance between achievement and relationships. Building a culture of this magnitude of mutual cooperation is through exemplary management and socialization methods. The end result is to make the workers feel part of the company, love their jobs, and want to stay and support company policies (Uddin, et al., 2013; Mahdiyeh, 2016; 2014; Muksin, 2017; Padhi, 2017).

\section{Literature Review}

\subsection{Theory of Planned Behavior}

This theory explains that behavior determined by individuals arises because there is an intention to behave or act in a particular way (Ajzen, 2002). It is determined by three factors namely (1) Behavioral beliefs that are about the results and its evaluation, (2) Normative beliefs that are beliefs about normative expectations of others and motivation to meet those expectations, and (3) 3. Control beliefs which are beliefs about the existence of things that support or inhibit the behavior that will be displayed and their perceptions to support and hinder this behavior.

This theory also states that a person acts based on intentions only if there is control on the behavior (Ajzen, 2002). This theory emphasizes the rationality of human behavior and the belief that behavioral targets are under the control of the individual's consciousness. Therefore, it does not only depend on one's intentions, but also on other factors that cannot be controlled by an individual (Ajzen, 2002). Based on this, one can see that intention is a function of three determinants, first is personal, the second reflects social influence, and the third is related to the problem of control (Ajzen, 2002).

\subsection{Socio-Cultural}

Socio-culture is a pattern in society which is bureaucratic in nature. It is organized, developed, and cultured with the theory of thought or the belief system and its application in everyday life. It is also described as something that cannot be explained by the ability of the five senses (Cicourel, 2013). Social behavior is determined by some stimulus that comes from self and the individual as an actor is not just a passive respondent but can also interpret the signal received. The society is however seen as a creative actor from social reality such that social change can occur and will have an impact on interactions (Rofiq, 2008).

Social interaction is interpreted as a changing mutual relationship that involves two parties which can be some individuals or groups of people, to achieve certain goals. These interactions occur because of mutual understanding of the intent of each party in the social relations. A sense of mutual understanding can then bring about dynamic interaction between one party and another and the objectives of a community program will tend to improve the quality of life (Pribadi, 2004).

The development of a social relationship is also explained through the goals of man who does it. When such an individual takes the benefits of the action, a difference that makes it more useful as a solution to social problems is created. Hence, communities that make use of cultural rule as the solution without considering other factors in solving problems will not be efficient in carrying out social activities (Darwis, 2003). 
Culture is easily influenced by the current development, thus it is susceptible to changes from time to time and might cause various problems. There is a socialist nature to it in terms of the bond that creates life together (Sulismadi\&Sofwani, 2011). However, culture includes a comprehensive understanding described and seen through various variables. It can also be seen as a comprehensive view of life, attitudes and values, whose development is associated with the efforts made to improve the ability of recovering from bad conditions and improving lives together establishing prosperity. In this case the social culture has a role of providing the best solutions for various fields of life (Widianto \& Pirous, 2009). The socio-cultural role of the community is therefore the determination, regulation and influencing of the actions or activities of a social group to fulfill various needs, thus socio-culture is the determinant of the society quality. If a society is too fixated on the local social culture, it will affect behaviors in the community (Jahidin et al. 2012).

\subsection{Stakeholder Theory}

Stakeholder theory says that a company is not an entity that only operates for its own interests, but also provides benefits to shareholders, creditors, consumers, suppliers, government, society, analysts and other parties. Thus, the existence of a company is strongly influenced by the support of the stakeholders (Ghozali \& Chariri, 2007). Deegan (2004) stated that stakeholder theory states that all stakeholders have the right to obtain information about company activities which is able to influence their decision making. Stakeholders are able to also choose not to use the information and may not play a direct role. This is in line with the triple bottom line reporting concept that focuses on the 3Ps, i.e. profit, people and the planet. This means that the existence of a business enterprise in an environment is not only seeking maximum profits, but also providing a high contribution to the communities around the company and nature that is a resource or input in the company's processes.

Stakeholder theory takes the interests of stakeholder groups that can influence a company's strategy into consideration because they are that part of the company with influence on the use of economic resources in all activities. Similarly, Ghozali \& Chariri (2007) stated that the survival of the company depends on the support of stakeholders which must be sought and pursued by the company's management. Stakeholders as a group or individual provide certain services to the company and also obtains gains from the the company. They have interest in the existence or activities of the company and therefore influences or gets influenced by the company's activities.

Stakeholder theory explicitly considers the impact of company disclosure policies when there are differences in the company. It is used as a management tool to handle the information needs of various sectors of the company. Therefore, management discloses their information in order to manage stakeholders and ensure their continued support since this disclosure affects the survival of the company as a whole (Gray, et al., 1995). Stakeholder theory further stated that the company has investors and non-investors such as customers, employees, suppliers, the surrounding community, and the government that are interested in it (Robbins \& Coulter, 2007).

\section{Discussion}

\subsection{The Noble Values of the Indonesian Nation}

The noble values of the nation are efforts to reason (cognition) and behave towards something, an object, or an event that occured in a particular place. These can also be viewed as explicit knowledge that emerged from a long period and has evolved together within the community in the local system that has been experienced together. These are not only a person's behavioral references, but are also considered the truths that have been in tradition and are able to dynamize the life of a civilized society (Gobyah, 2003). Also, they are rules applied in a society which is believed to be true and becomes a reference in acting and behaving. Therefore, they greatly determine human dignity and values in their community (Geertz, 2007). They are also a form of culture that experiences a continuous reinforcement which makes it a better cultural manifestation that can occur.

The nation's noble value is also a system developed by traditional communities that regulates the ethics of good and bad judgment. This establishment regulates customary matters that must be obeyed and has an associated sanction that govern it when violated. The philosophy of the republic of Indonesia is made from all these values developed in the community and they form the foundation of what is known as the Pancasila. Wikipedia defines Pancasila as a basic ideology for the Indonesian state and it the formula and guideline for the life of the nation. The precepts are furtger elaborated below.

First precepts of Pancasila: Believe in one supreme God. This percept has culture value as The Indonesian nation believes and fears God; Indonesian people's believe and fear God based on their respective religions and beliefs according to the basis of just and civilized humanity; Developing a habit of respecting and cooperating with religious followers having different beliefs towards God that is, having respect for fellow human beings; Fostering harmony of 
life among fellow religious people and belief in God; Religion and belief in God Almighty is a problem that concerns the personal relationship of human with God;Developing mutual respect for freedom of worship in accordance with their respective religions and beliefs; and; Not imposing a religion and trust in God to others;

Second precepts of Pancasila: A Just and civilized humanity. This precept has culture value as Recognizing and treating human beings according to their dignity as creations of God; Recognizing the equality of right and dignity, and basic obligations of every human being without discriminating between tribes, descendants, religions, beliefs, gender, social position, skin color and etc.; Developing mutual love for humans; Developing an attitude of mutual tolerance and impartiality; Developing a non-arbitrary attitude towards others; Upholding human values; Likeness to carry out humanitarian activities; Daring to defend truth and justice; The Indonesian nation feels itself as part of all humanity; Develop a habit of respecting and cooperating with other nations;

Third precepts of Pancasila: The unified Indonesia. This percept has culture value as Ability to place the unity, togetherness, interests and safety of the nation and state above personal and group interests; Ability and willingness to sacrifice for the benefit of the state and the nation at large; Developing love for the homeland; Developing a sense of pride and nationalism in Indonesia; Maintaining world order based on freedom, eternal peace, and social justice; Developing Indonesian unity on the basis of Unity in Diversity; Promoting association for national unity and togetherness; Fourth precepts of Pancasila: The democracy As citizens and part of community, every Indonesian has the same position, rights and obligations; You cannot force your will on others; Prioritizing deliberation in making decisions for common interests; Deliberation to reach consensus is covered by a spirit of family; Respecting and upholding every decision reached as a result of deliberation; Have good faith and a sense of responsibility to accept and implement the results of deliberation decisions; In the deliberation, mutual interests above personal and group interests are prioritized; Deliberations are conducted with intelligence and in accordance with a noble conscience; Decisions taken must be responsible to God Almighty, upholding human dignity, values of truth and justice, prioritizing unity and togetherness for the common good; Having faith in representatives who are trusted to carry out consultations;

Fifth precepts of Pancasila: Social justice for all Indonesian people. This percept has culture value as Developing noble deeds, which reflects attitude, kinship and mutual cooperation; Developing a fair attitude towards others; aintaining a balance between rights and obligations; Respecting the rights of others; Helpful to others in order to be able to stand alone; Do not use property rights for businesses that are extortion against others; Do not use perty rights for wasteful things and luxurious lifestyles; Not using property rights to conflict with or harm the public interest; Hardworking; Like respecting the work of thers which are beneficial to progress and mutual prosperity; Like doing activities to realize fairness and social justice development.

The five Pancasila details the activities carried out by the companies which were analyzed to become reported information. Although the activity was not related to the Pancasila, it nonetheless approached and reflected the points of the Pancasila. For example, in the Pancasila Precept 1 in points 1, 2 and 3, it can be explained that the information gotten from the company relates to the religious background of the leadership starting from the Board of Commissioners and the Board of Directors to the statistics of company employees based on their religion. Items 4, 5 and 6 explains information related to places of worship that are within the scope of corporate office areas and assistance provided by companies to the general public for the construction or renovation of religious facilities. Point 7 can be explained by information made by the company relating to its strategic plan that includes words related to religious life, such as devotion to God Almighty, improving harmony in religious life, sustenance derived from God and others.

Each point in the Pancasila precepts is analyzed below by using information disclosure. The results of analysis of information disclosure of company activities can be seen in table below;

Table 1. Analysis of the Pancasila points into company information

\begin{tabular}{ll}
\hline Points of Pancasila & Company Disclosures \\
\hline First precept: Believe in one supreme God & $\begin{array}{l}\text { Religious information about the company's } \\
\text { leadership }\end{array}$ \\
\hline The Indonesian believes and fears God &
\end{tabular}


Indonesian people believe and fear God, in accordance with Information on employee statistics based on their respective religions and beliefs according to the basis of religion

just and civilized humanity

Developing a habit of respecting and cooperating between Information on places of worship in office religious followers with different beliefs toward God; Respect for fellow human beings

Fostering harmony of life among fellow religious people and Information on commemorating religious belief in God holidays

Religion and belief in God Almighty is a problem that Information on company assistance towards the concerns the personal relationship of human with God construction of religious facilities

Developing mutual respect for freedom of worship in Religious information in the company's strategic accordance with their respective religions and beliefs plan

$\begin{array}{ll}\text { Not imposing a religion and trust in God on others } & \begin{array}{l}\text { Information on the location of worship around } \\ \text { the company's environment }\end{array}\end{array}$

\section{Second precept: Just and civilized humanity}

Recognizing and treating human beings according to their dignity as creations of God

Information on career development systems in company reports

Recognizing the equality of right and dignity, and basic obligations of every human being, without discriminating Salary and remuneration system information between tribes, descendants, religions, beliefs, gender, social position, skin color and etc.

\begin{tabular}{l}
\hline Developing mutual love for humans \\
\hline Developing an attitude of mutual tolerance and impartiality \\
\hline Developing a non-arbitrary attitude towards others \\
\hline Upholding human values
\end{tabular}

Information on equal rights and obligations that do not discriminate

Information on awards and sanctions Information on employee capacity building Information on settlement of disputes with employees or union employees

Actively carrying out humanitarian activities Information on collaboration collaboration with other companies

Daring to defend truth and justice Information on the location of complaintsor LBH related to unrighteousness and injustice

Indonesian nation feels itself as part of all humanity Information on being a member or sympathizer of Indonesian and International humanitarian institutions (Unicef, Aksi Cepat Tanggap (ACT), Dompet Duafa, Laznas BSM, Laznas Al Azhar, Majelis Ta'lim Telkomsel, SADAQA, KAMMI Peduli House, Daily Alms Community, Idea Society Sharing, Successful Zakat)

Develop a habit of respecting and cooperating with other Information on being a sympathizer or member nations of the Indonesian Red Cross

\section{Third precept: The unified Indonesia}

Ability to place the unity, togetherness and interests and safety of the nation and state above personal and group Information on the number of Indonesian citizens interests

$\begin{aligned} & \text { Able and willing to sacrifice for the benefit of the state and } \\ & \text { nation }\end{aligned}$
$\begin{array}{ll}\text { Developing love for the homeland and nation } & \text { Information on ceremonies commemorating }\end{array}$


state holidays

Developing a sense of pride and nationalism in Indonesia Information about company leaders from various religions and tribes

Maintaining world order based on freedom, eternal peace, and social justice

Information on company participation in disaster charity activities

Developing Indonesian unity on the basis of Unity in Information on company compliance with Diversity international regulations

Promote association for national unity and togetherness Information on cooperation with TNI or PORLI

\section{Fourth precept: The democracy}

As citizens and part of community, everyone has the same position, rights and obligations

Information on the process of hiring employees who provide opportunities for Indonesian citizens

You cannot force your will on others Information on decision making conducted by deliberation and consensus

Prioritizing deliberation in making decisions for common interests

Information on job descriptions of company leaders and their respective responsibilities

Deliberation to reach consensus is covered by a spirit of family

Information on opinions of public accounting firms and other reports

Respecting and upholding every decision reached as a result of deliberation

Information on the number of community complaints that were followed up

Have good faith and a sense of responsibility to accept and Information on company policies related to implement the results of deliberation decisions leave rights

In the deliberation, mutual interests above personal and group interests are prioritized Information on the existence of Tripartite cooperation institutions (trade unions, employers and government)

Deliberations are conducted with intelligence and in Information on the existence of Bipartite accordance with a noble conscience cooperation institutions (trade unions and employers)

Decisions taken must be responsible to God Almighty, Information on cooperation with religious upholding human dignity, values of truth and justice, Assembly institutions prioritizing unity and togetherness for the common good

Having faith in representatives who are trusted to carry out Information on cooperation with institutions or consultations members of the Parlement

\section{Fifth precept: Social justice for all Indonesian people}

Developing noble deeds, which reflect the attitude, kinship Information on the involvement of companies in and mutual cooperation the social environment

Developing a fair attitude towards others Information on company waste recycling activities

Maintaining a balance between rights and obligations Information on company activities related to the economic development of the community

Respecting the rights of others Information on the recognition of employee creativity and innovation

Helpful to others in order to be able to stand alone Information on company slogans related to curroption, gratuities, extortion, efficiency and simplicity.

Do not use property rights for businesses that are extortion Information on the amount of taxes, dividends 
against others

Do not use property rights for wasteful things and luxurious lifestyles

Not using property rights to conflict with or harm the public interest

Hardworking and zakat / infaq / alms

Information on the existence of a circular letter from the leadership regarding the procedures for using resources in the company environment

Information on a circular letter regarding sanctions for theft within the company

Information on the existence of rewards / rewards for human resources who work on normal workloads

Like doing activities to realize fairness and social justice development
Information on cooperation with the Director General of Intellectual Property / Copyright institutions

\subsection{Pancasila Corporate Governance Index (PCGI)}

PCGI is used ro calculate the implementation of social values in the society using variabler eflected in the GCG. The disclosure of this information is observed in the company's annual report by paying attention to the language used and the variable calculation is conducted by measuring the information disclosure of the Pancasila precepts in the annual report. Classification is then computed using a data checklist and representing each answer with the corresponding codes. If a point of information is not in the financial statements, a score of 0 is given; however, a score of 1 is given if the specified information is in the annual report. Using these variables, calculations are carried out by researchers using the Pancasila Corporate Governance Index (PCGI).

\begin{tabular}{ll}
\hline The implementation of Pancasila in Corporate Governance & D ND \\
\hline First precept: believe in one supreme God \\
\hline 1) & Religious information about the company's leadership \\
\hline 2) & Information on employee statistics based on religion \\
\hline 3) & Information on places of worship in office \\
\hline 4) & Information on commemorating religious holidays \\
\hline 5) & Information on company assistance for the construction of religious facilities \\
\hline 6) & Religious information in the company's strategic plan \\
\hline 7) & Information on the location of worship around the company's environment \\
\hline Second precept: Just and civilized humanity \\
\hline 1) & Information on career development systems in company reports \\
\hline 2) & Salary and remuneration system information \\
\hline 3) & Information on equal rights and obligations that do not discriminate \\
\hline 4) & Information on awards and sanctions \\
\hline 5) & Information on employee capacity building \\
\hline 6) & Information on settlement of disputes with employees or union employees \\
\hline 7) & Information on internal collaboration or collaboration with other companies \\
\hline 8) & Information on the location of complaints or LBH related to unrighteousness and \\
injustice \\
\hline 9) & Information on being a member or sympathizer of Indonesian and International \\
humanitarian institutions \\
\hline 10) & Information on being a sympathizers or member of the Indonesian Red Cross \\
\hline
\end{tabular}




\section{Third precept: The unity of Indonesian}

1) Information on the number of Indonesian citizens

2) Report information on Indonesian

3) Information on ceremonies commemorating state holidays

4) Information about company leaders from various religions and tribes

5) Information on company participation in disaster charity activities

6) Information on company compliance with international regulations

7) Information on cooperation with army and police

\section{Forth precept: The democracy led by understanding wisdom among honorable} representatives from the parliament house

1) Information on the process of hiring employees who provide opportunities for Indonesian citizens

2) Information on decision making conducted by deliberation and consensus

3) Information on job descriptions of company leaders and their respective responsibilities

4) Information on opinions of public accounting firms and other reports

5) Information on the number of community complaints that were followed up

6) Information on company policies related to leave rights

7) Information on the existence of Tripartite cooperation institutions (trade unions, employers and government)

8) Information on the existence of Bipartite cooperation institutions (trade unions and employers)

9) Information on cooperation with religious Assembly institutions

10) Information on cooperation with institutions or members of the Parlemen

\section{Fifth precept: Social justice for all Indonesian people}

1) Information on the involvement of companies in the social environment

2) Information on company waste recycling activities

3) Information on company activities related to the economic development of the community

4) Information on the recognition of employee creativity and innovation

5) Information on company slogans related to $\mathrm{KKN}$, gratuities, extortion, efficiency and simplicity.

6) Information on the amount of taxes, dividends and zakat / infaq / alms

7) Information on the existence of a circular letter from the leadership regarding the procedures for using Resources in the company environment

8) Information on a circular letter regarding sanctions regarding theft within the company

9) Information on the existence of rewards for human resources who work on normal workloads

10) Information on cooperation with the Director General of Intellectual Property / Copyright institutions

From the results of the checklist, the index of Pancasila implementation in GCG is calculated using the following formula: 


$$
\text { PCGI }=\sum_{i=1}^{n} d_{i}
$$

Where: PCGI $=$ Pancasila Corporate Governance Index, $\mathrm{n}=$ number of disclosure items

\section{Conclusion}

Pancasila as the implementation of noble values in Indonesia makes GCG easy to administer and achieve goals as expected. This was so because the GCG building focused on social culture in the lives of the Indonesian nation. PCGI is an indicator of information disclosure related to the values of social culture in the lives of people in the company's annual report. However, with the increase in PCGI, there are increasing social cultural values that exist in the lives of Indonesian and are implemented in corporate GCG.

\section{References}

Abdelsalam, O., El-Masry, A., \& Elsegini, S. (2008). Board Composition, Ownership Structure and Dividend Policies in an Emerging Market: Further Evidence from CASE 50. Managerial Finance, 34(12), 953-964.

Abdul Rahman, R., \& Mohammed Ali, F. H. (2006). Board, Audit Committe, Culture and Earning Management: Malaysian Evidence. Managerial Auditing Journal, 21(7), 783-804.

Adam, M., Mukhtaruddin, Soraya, N., \& Yusriati, H. (2015). Good Corporate Governance and Cost of Debt: Study on Listed Companies Listed on Indonesia Institute of Corporate Governace. Asian Social Science, 11(25), 58-77. https://doi.org/10.5539/ass.v11n25p58

Adeniyi, S. I., \& Fadipe, A. O. (2018). Effect of Board Diversity on Sustainability Reporting in Nigeria: A Study of Beverage Manufacturing Firms. Indonesian Journal of Corporate Social Responsibility and Environmental Management, 1(1), 43-50.

Agustina, D. (2017). Pengaruh Corporate Governance dan Variabel Keuangan Terhadap Nilai Perushaan. Jurnal Bisnis dan Akuntansi, 19(1), 13-26. https://doi.org/10.34208/jba.v19i1.61

Ali Shah, S. Z., Ali, B. S., \& Hasan, A. (2009). Corporate Governance and Earning Management an Empirical Evidence from Pakistani Listed Company. European Journal of Scientific Research, 26(4), 624-638.

Almaqoushi, W., \& Powel, R. (2017). Audit Committee Indices, Firm Value and Accounting Outcomes. Social Sciences Research Network, 1-59. https://doi.org/10.2139/ssrn.2959718

Al-Najjar, B., \& Hussainy, K. (2009). The Association between Dividend Payout and Outisde Directoreship. Journal of Applied Accounting Research, 10(1), 4-19. https://doi.org/10.1108/09675420910963360

Alqatamin, R. M. (2018). Audit Committee and Company Performance: Evidence from Jordan. Accounting and Finance Research, 7(2), 48-60. https://doi.org/10.5430/afr.v7n2p48

Aluchna, M. (2015). Corporate Governance versus Ethics: The Case of Goldman Sachs. Journal of Management and Financial Sciences, 8(12), 107-130.

Anderson, C. (2015, May). Culture; The Key to Corporate Governance. Ethisphere Magazine.

Arshad, S., Asif, R., \& Baloch, M. A. (2012). The Impact of Fairness in Working Conditions on Organizational Performance in Pakistan Telecomunication Company Listed in Islamabad. International Journal of Economics and Management Sciences, 2(4), 10-19.

Bachev, H. (2018). Efficiency of Environmental and Sustainability Management in Bulgarian Agriculture. Indonesian Journal of Corporate Social Responsibility and Environmental Management, 1(1), 29-42.

Baxamusa, M., \& Jalal, A. (2013). Does Religion affect Capital Structure. Research in International Business and Finance, 31(1), 112-131. https://doi.org/10.1016/j.ribaf.2013.09.003

Boachen, E., \& Mamatzakis, E. (2016). Do Religion, Corporate Governance and Big 4 Audit Interactions affect Misclassification. Munich Personal RePEC Achive Conference Paper No. 76804.

Boediono, G. S. B. (2005, September 15-16). Kualitas Laba: Studi Pengaruh Corporate Governance dan dampak Manajemen Laba dengan Menggunakan Analisis Alur. Simposium Nasional Akuntansi VIII, Solo.

Butar-Butar, A., \& Siregar, C. T. (2008). Karakter Pasien dan Kualitas Hidup Pasien Gagal Ginjal Kronis yang Menjalani Terapi Hemodialisa. Penelitian Tidak Dipublikasikan. 
Cai, J., \& Shi, G. F. (2017). Do Religious nomrs Influence Corporate Debt Financing?. Journal of Business Ethics, 145(1), 1-24. https://doi.org/10.1007/s10551-017-3701-5

Callen, J. L., \& Fang, X. H. (2015). Religion and Stock Price Crash Risk. Journal of Finance and Quantitative Analysis, 50(1/2), 169-195. https://doi.org/10.1017/S0022109015000046

Castro, C. E., Desender, K. A., \& Escamilla, S. A. (n.d.). Earning Management and Share Cultural Values. Working Paper, Preliminary Draft.

Cheng, S., \& Michael, F. (2006). Family Ownership, Corporate Governance, and Top Executive Compensation. Managerial and Decision Economic, 27, 549-561. https://doi.org/10.1002/mde.1273

Claessens, S., Djankov, S., Fan, J. P. H., \& Lang, L. H. P. (2002). Disentangling the incentive and entrenchment effects of large shareholdings. The Journal of Finance, 57(6), 2741-2771.

Darmawati, D. (2006, Agustus 23-26). Regulasi Terhadap Kualitas Implementasi Corporate Governance. Simposium Nasional Akuntansi IX, Padang.

Debby, J. F., Mukhtaruddin, Yuniarti, E., \& Saputra, D. (n.d.). Good Corporate Governance, Company Characteristics and Firm Value: Empirical Study of Listing Banking on Indonesia Stock Exchange. GSTF Journal on Business Review, 2(4), 81-88.

Dewi, K., Mukhtaruddin, \& Apriany, C. (2014). Good Corporate Mechanism, Firm Characteristics, Corporate Social Responsibility: Empirical Study in Manufacturing Companies Listed in Indonesia Stock Exchange. International Journal of Finance and Accounting, 3(2), 88-95. https://doi.org/10.5176/2251-1997_AF14.47

Dharmadasa, P., Herath, S., \& Gamage, P. (2014). Corporate Governance, Board Characteristics and Firm Performance: Evidence from Sri Lanka. Journal of South Asia Development, 21(1), 7-31.

Diab, S. M. (2015). The Impact of Organizational Justices on the Workers Performance and Job Satisfaction in the Ministry of Health Hospital in Amman. International Business Research, 8(2), 187-197.

Duman, F. (2012). The Roots of Modern Feminism: Mary Wollstonecraft and the Frech Revolution. International Journal of Humanities and Social Science, 2(9), 75-89.

Farinha, J. (2002). Dividend Policy, Corporate Governance and Managerial Entrenchment Hypothesis: An Empirical Analysis. Working Paper. https://doi.org/10.2139/ssrn.313976

Frank, M., \& Jaganathan, R. (1998). Why do Stock Prices Drop by Less than the Value of the Dividend. Evidence From a Country Without Taxes. Journal of Financial Economics, 47, 161-188.

Giovannini, R. (2010). Corporate Governance, Family Ownership and Performance. Journal of Management and Governance, 14(2), 146-166. https://doi.org/10.1007/s10997-009-9093-x

Griffin, D., Kwok, C. C. Y., Guedhami, O., Li, K., \& Shao, L. (2014). National Culture, Corporate Governance Practices, and Firm Performance. Seminars Northen Finance Association Meetings and FMA Asian Conferece (pp. 1-62), Tokyo. https://doi.org/10.2139/ssrn.2400078

Grove, H., \& Basilico, E. (2011). Major Financial Reporting Frauds of the 21st Century: Corporate Governance and Risk Lessons Learned. Journal of Forensic and Investigative Accounting, 3(2), 194-236.

Harung, H. S. (1995). Enhancing Organizational Performance by Strengthening Diversitu and Unity. The Learning Organization, 2(1), 9-21. https://doi.org/10.1108/09696479510092481

Hasan, R., \& Yun, T. M. (2017). Theoretical Linkage between Corporate Social Responsibility and Corporate Reputation. Indonesian Journal of Sustainability Accounting and Management, 1(2), 80-89.

Hastuti, T. D. (2005, September 15-16). Hubungan Antara Good Corporate Governance dan Struktur Kepemilikan Dengan Kinerja Keuangan. Simposium Nasional Akuntansi VIII, Solo.

Helleiner, G. K. (2001). Markets, Politics, and Globalization: Can the Global economy be Civilized?. Journal of Human Development, 2(1), 27-46. https://doi.org/10.1080/14649880120050165

Hermanto, B., \& Rusdin. (2013). Budaya Organisasi, Penciptaan Nilai dan Kinerja Organisasi. Jurnal Administrasi Bisnis, X(2), 2982-2994.

Hill, R. P., \& Rapp, J. M. (2014). Codes of Ethical Conduct: A Bottom-Up Approach. Journal of Business Ethics, 123, 621-630. https://doi.org/10.1007/s10551-013-2013-7 
Imran, R. F. Z., \& Zaheer, A. (2012). Leadership and Performance: Culture Matters. International Journal of Innovation, Management and Technology, 3(6), 713-717.

Jaja, S. A., \& Ugwuzar, M. (2014). Unity in Diversity: Implications for Managers. European Journal of Business and Management, 6(15), 176-183.

Jensen, M., \& Meckling, W. H. (1976). The theory of the firm: Managerial behavior, agency costs and ownership structure. Journal of Financial Economics, 3(4), 305-360. https://doi.org/10.1016/0304-405X(76)90026-X

Jepsen, D. M., \& Rodwell, J. (2017). Using Organizational Justices to predict in-role and extra-role performance worker in Different ways for men relative to women. Anzam 2017: Managing our Intellectual and Social Capital, 21th Anzam Conference, Sydney

Junaedi, A., \& Farina, K. (2017). Pengaruh Efektifitas Dewan Komisaris dan Komite Audit, Struktur Kepemilikan Perusahaan, dan Kualitas Audit terhadap Perataan Laba. Jurnal Manajemen Bisnis Krisnadwipayana, 5(1), 1-17. https://doi.org/10.35137/jmbk.v5i1.81

Kalay, F. (2016). The Impact of Organizational Justices on Employee Performance: A Study Turkey and Turkish Context. International Journal of Human Resources Studies, 6(1), 1-20. https://doi.org/10.5296/ijhrs.v6i1.8854

Kamarudin, S., Baharum, R., Tee, R., \& Liaw, J. O. H. (2013). Religious faith and its affect on Enterpreneurial value, marketing and Human Resouces Strategy and Business Performance: an Empirical study. Prosiding paper on 5th International conference on Humanities and Social Sciences.

Klien, P., Shapiro, D., \& Jeffrey, Y. (2005, November). Corporate Governance, Family Ownership amd Firm Value: The Canadian Evidence. Corporate Governance, 13(6). https://doi.org/10.1111/j.1467-8683.2005.00469.x

Koech, P. M., \& Numosonge, G. S. (2012). The effect of Leadership Styles on Organizational Performance at State Corporation in Kenya. International Journal of Business and Commerce, 2(1), 1-12.

Kotter, J. P., \& Heskett, J. L. (1992). Corporate Culture and Performance. New York: Free Press.

Kowalewski, O., Stetsyuk, I., \& Oleksandr, T. (2007). Corporate Governance and Dividend Policy in Poland. Working Paper, Preliminary Draft. https://doi.org/10.2139/ssrn.986111

Kusi-Mensah, P., Daboug, C. B., \& Opoki, R. (2007). The influence of religion on Cpaital Structure decision among small and medium enterprise in Ghana. Research Journal of Finance and Accounting, 8(4), 126-141.

Lestari, E., \& Murtanto. (2018). Pengaruh Efektifitas Dean Komisaris dan Komite Audit, Struktur Kepemilikan dan Kualitas Audit terhadap Manajemen Laba. Jurnal Media Riset Akuntansi, Auditing dan Informasi, 17(12), 97-116. https://doi.org/10.25105/mraai.v17i2.2063

Lestari, I. B., Hamzah, N., \& Maelah, R. (2019). Corporate Social and Environmental Strategy and Reporting in Indonesian Plantation Industry. Indonesian Journal of Sustainability Accounting and Management, 3(1), 84-94.

Llopis, J., Gasco, J., \& Gonzales, R. (2007). Corporate Governance and Organizational Culture. International Journal of Disclosure and Governance, 4(2), 1-16. https://doi.org/10.1057/palgrave.jdg.2050051

Mahdiyeh, M., Nakhaei, H., \& Kebriaei, A. (2016). Impact of Organizational Culture on Productivity: A Study among Employee of Ministry of Youth and Sport Iran. International Journal of Humanities and Culture Study, 3(3), 169-177.

Maryati. (2018). Reaksi Pasar atas Pengungkapan Modal Intelektual, Penerapan Prinsip-prinsip Good Corporate Governance dan Nilai Perusahaan: Studi Empiris Perusahaan Perbankan di 5 Negara ASEAN 2015 - 2016. Tesis S2 Universitas Mercu Buana, Jakarta.

Mitton, T. (2004). Corporate Governance and Dividend Policy in Emerging Markets. Working Paper. https://doi.org/10.1016/j.ememar.2004.05.003

Mohamed, S. A. (2014). The Relationship between Organizational Justices and Quality of Performance among Healthcare Worker: A Pilot Study. The Sicentific World Journal, 1-7. https://doi.org/10.1155/2014/757425

Molnar, L. (2015). Analysis of the Relationship among Innovation, Performance, Economics Development and Social Welfare. Journal Economics Literatur, 11(1), 71-78. https://doi.org/10.18096/TMP.2015.01.07

Mukhsin, M. (2017). Kepemimpinan Islami, Budaya Kerja Islami dan Produktifitas Kerja Karyawan. Syi'ar Iqtishadi: Journal of Islamic Economics, Finance and Banking, 1(2), 204-229. 
Mukhtaruddin, M., Ubaidillah, U., Dewi, K., Hakiki, A., \& Nopriyanto, N. (2019). Good Corporate Governance, Corporate Social Responsibility, Firm Value, and Financial Performance as Moderating Variable. Indonesian Journal of Sustainability Accounting and Management, 3(1), 55-64. https://doi.org/10.28992/ijsam.v3i1.74

Mukhtaruddin, R., \& Felmania, M. (2014). Good Corporate Governance Mechanism, Corporate Social Responsibility on Firm Value - Empirical Study on Listed Company in Indonesia Stock Exchange. International Journal of Fianance and Accounting Studies, 2(1), 1-10.

Muntoro, R. K. (2006). Membangun Dewan Komisaris yang Efektif. Makalah Tidak Publikasi.

Nalina, B., \& Panchanatham, N. (2016). Corportae Governance-The Importance of Communication and Culture. Indian Journal of Science and Technology, 9(33), 1-4. https://doi.org/10.17485/ijst/2016/v9i33/98510

Ng. Christina, Y. M. (2005). An Empirical Study on The Relationship Between Ownership and Performance in a Family-Based Corporate Environment. Journal of Accounting, Auditing and Finance, 20(2), 121-146.

Ntongho, R. A. (2016). Culture and Corporate Governance. International Journal of Law and Management, 58(5), 523-544. https://doi.org/10.1108/JJLMA-04-2015-0016

Odoemelam, N., \& Okafor, R. G. (2018). The Influence of Corporate Governance on Environmental Disclosure of Listed Non-Financial Firms in Nigeria. Indonesian Journal of Sustainability Accounting and Management, 2(1), 25-49. https://doi.org/10.28992/ijsam.v2i1.47

Ordu, A. (2016). The effect of Diversity Management on Job Satisfaction and Individual Performance of Teacher. Educational Research and Reviews, 11(3), 105-112. https://doi.org/10.5897/ERR2015.2573

Osborne, S. (2017). Kulini: Framing Ethical Listening and Power-Sensitive Dialogue in Remote Aboriginal Education and Research. Learning Communities, Special Issues: Decolonising Research Practices, 22, 26-37.

Padhi, P. (2017). Organizational Culture and Employee Performance. International Journal of Research in IT and Management, 7(5), 77- 81.

Peasnell, K. V., Pope, P. F., \& Young, S. (n.d.). Outside Directors, Effectiveness, and Earning Management. Draft Working Paper.

Pradeep, D. D., \& Prabhu, N. R. V. (2011). The Relationship between Effective Leadership and Employee Performance. International Conference on Advancement in Information Technology With Workshop ICBMG, 20.

Price, N. J. (2018). Boardroom Best Practices: The Importance of Corporate Culture of Good Governance.

Rahman, U. B. A. M. (2002). The Effect of Religion on Earning Management and Capital Structure: Evidence from Muslim and Non-Muslim Managed Firms in Malaysia. Theis in College of Business, Massey University.

Sarapatka, J. (2016). Catholic Religion, Corporate Governance and Executive Compensation. Thesis in Faculty of Social Sciences, Charles University of Praque.

Sarwono, A. E., Rahmawati, R., Aryani, Y. A., \& Probohudono, A. N. (2018). Factors Affecting Corruption in Indonesia: Study on Local Government in Indonesia. Indonesian Journal of Sustainability Accounting and Management, 2(2), 79-89. https://doi.org/10.28992/ijsam.v2i2.41

Sibarani, R. (2012). Kearifan Lokal: Hakikat, Peran dan Metode Tradisi Lisan. Jakarta: Asosiasi Tradisi Lisan.

Susanto, K., Sasmita, P. K., Desyi, Limantara, A. L., \& Halim, F. (2014). Apakah Jenis Kelamin Berpengaruh Terhadap Jenis Kecerdasan Ganda. Damianus: Journal Medicine, 13(1), 1-8.

Sutojo, S., \& John, A. E. (2006). Good Corporate Governance, Tata Kelola Perusahaan yang Sehat. PT. Damar Mulia Pustaka, Jakarta.

Uddin, M. J., Luva, R. H., \& Hossain, S. Md. M. (2013). Impact of Organizational Culture on Employee Performance and Productivity: A Case Study of Telecomunication Sectors in Bangladesh. International Journal of Business and Management, 8(2), 63-77. https://doi.org/10.5539/ijbm.v8n2p63

Volonte, C. (2014). Culture and Corporate Governance: The Influence of Language and Religion in Switzerland. Management International Review. https://doi.org/10.1007/s11575-014-0216-5

Yosinta, O. (2016). Organizational Culture and Good Governance in Public Sector: The Case of Provincial Administration in Thailand. Thesis of Doctoral of Philosopt, College of Social Science University of Birmingham. 